Journal Club

Editor's Note: These short reviews of recent JNeurosci articles, written exclusively by students or postdoctoral fellows, summarize the important findings of the paper and provide additional insight and commentary. If the authors of the highlighted article have written a response to the Journal Club, the response can be found by viewing the Journal Club at www.jneurosci.org. For more information on the format, review process, and purpose of Journal Club articles, please see http://jneurosci.org/content/ preparing-manuscript\#journalclub.

\title{
APP Modulates A $\beta$-Induced Activation of Microglia in Mouse Model of Alzheimer's Disease
}

\author{
Dibyadeep Datta \\ Department of Neuroscience, Yale University, New Haven, Connecticut 06510 \\ Review of Manocha et al.
}

Our understanding of the events involved in the pathophysiology of Alzheimer's disease $(\mathrm{AD})$ has undergone significant revisions during the last few decades. It has been proposed that accumulation and deposition in CNS parenchyma of amyloid- $\beta$ peptide $(A \beta)$, either from excessive amyloidogenic processing of the $\beta$-amyloid precursor protein (APP) or aberrant elimination of $\mathrm{A} \beta$ peptides, is a core pathological event in the pathogenesis of the illness. Abnormal A $\beta$ processing was thought to be followed by intraneuronal aggregation of hyperphosphorylated tau, a microtubule-associated protein normally localized in the axon, which produces neurofibrillary tangles (NFTs) and neuropil threads. Eventually, the accumulation of these pathological hallmarks was thought to be accompanied by astrogliosis and activation of neuroinflammatory processes, leading to neuronal and synaptic dysfunction and culminating in cognitive decline (Hardy and Selkoe, 2002; Wyss-Coray and Rogers, 2012).

A major assumption in the $\mathrm{AD}$ field has been that neuroinflammation reflects terminal stages of the disease progression and a consequence of neurodegeneration

Received Oct. 7, 2016; revised Nov. 10, 2016; accepted Nov. 21, 2016. The authors declare no competing financial interests.

Correspondence should be addressed to Dr. Dibyadeep Datta, Department of Neuroscience, Yale University, 333 Cedar Street, New Haven, CT 06510. E-mail: dibyadeep.datta@yale.edu.

DOI:10.1523/JNEUROSCI.3122-16.2017

Copyright $\odot 2017$ the authors $\quad 0270-6474 / 17 / 370238-03 \$ 15.00 / 0$ mediated by amyloid and tau pathology. However, many recent genetic, preclinical, and neuroimaging studies challenge this notion and suggest that neuroinflammatory mechanisms can cause neurodegeneration and exacerbate AD pathology, setting up a vicious pathophysiological cycle. In agreement with this, a compelling study by Manocha et al. (2016) in The Journal of Neuroscience demonstrates that A $\beta$ can directly interact with APP to stimulate activation of CNS resident immune cells known as microglia. These microglial cells are derived from the developing mesenchyme in which myeloid progenitors produce cells that translocate to the CNS and proliferate as microglia (Rezaie and Male, 2002). A $\beta$ deposits have long been known to be particularly potent at stimulating microglial activation, as indicated by the high concentration of microglia expressing MHCII and other markers of activation around these deposits in postmortem brain samples from patients with AD (McGeer et al., 1988). Recruitment of microglia to newly formed $\mathrm{A} \beta$ plaques occurs rapidly, and there appears to be a dynamic interaction between $\mathrm{A} \beta$ and immune-related pathways (Bolmont et al., 2008; Meyer-Luehmann et al., 2008). However, the exact nature of the interaction between $\mathrm{A} \beta$ and microglia remained to be elucidated. The studies performed by Manocha et al. (2016) examine this interaction and offer insight that may reconcile the amyloid cascade hypothesis and neuroinflammation hypothesis of $\mathrm{AD}$ (Hardy and Selkoe, 2002; Wyss-Coray and Rogers, 2012).

Using primary microglial cultures derived from wild-type and microglial APP knock-out ( $\mathrm{mAPP}^{-/-}$) mice, Manocha et al. (2016) investigated the ability of oligomeric and fibrillar $\mathrm{A} \beta$ to activate microglia. $\mathrm{A} \beta$ can exist in various aggregation states, including soluble oligomers as well as insoluble $\beta$-pleated amyloid fibrils that are the main component of dense-core plaques, and these states differ in their ability to prime microglial cells for activation following a stimulus (Heppner et al., 2015). The authors discovered that fibril$\operatorname{lar} A \beta$ induced upregulation of protein phosphotyrosine and proinflammatory cytokine TNF- $\alpha$ in both wild-type and $\mathrm{mAPP}^{-1-}$ cultures. However, oligomeric $\mathrm{A} \beta$ stimulation of phosphotyrosine and TNF- $\alpha$ in $\mathrm{mAPP}^{-/-}$cultures were significantly attenuated in the absence of APP, although the increases in phosphotyrosine and TNF- $\alpha$ were observed in control cultures.

Using intracerebroventricular infusion of $\mathrm{A} \beta$, Manocha et al. (2016) recapitulated the in vitro findings that $\mathrm{A} \beta$ stimulates microglial activation in wildtype and $\mathrm{mAPP}^{-1-}$ microglia in vivo. Total protein phosphotyrosine levels were elevated across multiple brain areas, including the frontal cortex, temporal cortex, hippocampus, and cerebellum. Furthermore, CD68, a marker for micro- 
gliosis, was elevated across the same brain regions and levels were correlated with phosphotyrosine levels. Importantly, $A \beta$ administration was associated with a concomitant reduction in putative presynaptic and postsynaptic markers, including syntaxin, synaptophysin, and PSD95, consistent with the enhanced microgliosis. The association of microglial activation with the loss of synaptic markers is particularly compelling in light of recent discoveries that support a potential role of microglia in normal synaptic remodeling (Nimmerjahn et al., 2005; Wake et al., 2009).

Using transgenic AD mouse models harboring $\mathrm{AD}$-linked mutations (i.e.,APP/ PS1 mutants) that affect the generation and propensity to aggregate $\mathrm{A} \beta$, the authors argue that endogenous APP is necessary for $\mathrm{A} \beta$ plaque-associated microgliosis. To test this, the authors created a new mouse strain by crossing mice with APP knock-out ( $\mathrm{mAPP}^{-1-}$ ) in microglia with APP/PS1 mutants, resulting in the generation of APP/PS1XmAPP ${ }^{-1-}$ mice. These mice had attenuated microgliosis compared with APP/PS1 mice, reflected in lower immunoreactivity for several markers of microglial activation, including CD68, CD11b, and Iba-1, along with reduced proliferation and chemokinestimulated migratory ability. By analyzing transcript levels for various proinflammatory (e.g., TNF- $\alpha$ and IL-6) and antiinflammatory cytokines (e.g., IL-10) by RT-PCR, the authors found significantly attenuated expression levels of TNF- $\alpha$ and IL-6, consistent with reduced microgliosis in the brain of APP/PS1XmAPP ${ }^{-/-}$mice.

Using ELISA analysis, the authors showed that $\mathrm{A} \beta$ oligomers interacted with APP in a dose-dependent manner, whereas fibrillar $\mathrm{A} \beta$ was unable to bind to APP. $\mathrm{A} \beta$ binding was suppressed with an antibody against cell surface APP receptors, indicating that the interaction was specific. These findings are consistent with the idea that, compared with fibrils, $\mathrm{A} \beta$ oligomers are more prone to induce synaptotoxicity and impair synaptic plasticity (Hsia et al., 1999; Mucke et al., 2000; Walsh et al., 2002).

To investigate the behavioral phenotype of APP/PS1XmAPP ${ }^{-1-}$ mice, the authors used several tests, including the open-field, light/dark box, and T-maze tests. The APP/PS1XmAPP ${ }^{-1-}$ mice had better memory performance, increased exploratory behavior, and diminished anxiety-like behavior compared with APP/PS1 mice, consistent with the bio- chemical, histological, and molecular analyses.

In aggregate, Manocha et al. (2016) identify a novel mechanism by which microglial APP plays a pivotal role in modulating microglial migratory ability and inflammatory activation in response to $\mathrm{A} \beta$ stimulation. The authors posit that $\mathrm{A} \beta$ secretion might occur from various cells and affect microglia in a paracrine manner and that $\mathrm{A} \beta$ might also be synthesized from microglial APP and regulate microglia in an autocrine manner. In conjunction with other lines of evidence, these findings reinforce the notion that neuroinflammatory processes occupy a central role in the pathogenesis of $\mathrm{AD}$. The insights gleaned from studies, such as this, significantly enhance our understanding of the disease process involved in $\mathrm{AD}$ and offer the promise of delivering novel therapeutic targets and plausible biomarkers relevant to diagnostics.

These findings are in accord with recent studies suggesting that complement cascade signaling and microglial activation mediate early synapse loss and neurite dysfunction in $\mathrm{AD}$ mouse models and that aberrant reactivation of developmental synaptic pruning pathways might drive the pathogenesis of the illness (Kettenmann et al., 2013; Hong et al., 2016). Resident microglia in adult CNS were found to phagocytose synapses when exposed to synaptotoxic $\mathrm{A} \beta$, and genetic deletion of downstream complement component C3 ameliorated synapse loss in APP/PS1 mice (Hong et al., 2016). These studies present microglia as potential cellular mediators of synaptic dysregulation, the strongest correlate of cognitive decline in $\mathrm{AD}$ (DeKosky and Scheff, 1990; Hong et al., 2016). Indeed, PET, using benzodiazepine ligands to track activated microglia, has revealed a robust increase in signal intensity in $\mathrm{AD}$ patients compared with matched healthy control subjects, along with a negative correlation between microglial load and cognitive status scores (Edison et al., 2008). Furthermore, the ability of using markers of inflammation as biomarkers for disease progression is validated by recent clinical trials in patients with $\mathrm{AD}$, which reported that intravenous infusions of antibody-based immunotherapy known as aducanumab (BIIB037) against $\mathrm{A} \beta$ reduced soluble $\mathrm{A} \beta$ oligomers and insoluble $\mathrm{A} \beta$ fibrils, in a dose- and time-dependent manner (Sevigny et al., 2016). Preclinical mechanistic studies have shown that aducanumab can penetrate the blood-brain barrier and engage $A \beta$ species with a high degree of specificity and clear plaque deposits. Importantly, elimination of toxic $\mathrm{A} \beta$ oligomers and fibrils was associated with enhanced recruitment of microglia and slowing of cognitive decline in patients with $\mathrm{AD}$, suggesting that the clinical benefit of the pharmacological agent might be mediated by the interaction between $\mathrm{A} \beta$, microglia, and immune-related pathways (Sevigny et al., 2016).

Several studies suggest that innate immunity receptors in addition to APP can influence microglial localization and phagocytosis capabilities. For example, the receptor for advanced glycation endproducts can directly interact with $\mathrm{A} \beta$ to modulate microglial proliferation and recruitment to plaques, a phenomenon that can be reversed by blockade of the receptor for advanced glycation endproducts with antibodies (Chen et al., 2007). Finally, it remains to be determined whether NFTs, which have a stereotypical spatiotemporal progression that correlates significantly with cognitive impairments in AD patients (Braak and Braak, 1991), can also induce microglial activation, culminating eventually in synapse loss and dysfunction and further exacerbating AD pathology.

In conclusion, Manocha et al. (2016) have identified what may be a crucial pathogenic mechanism in $\mathrm{AD}$ : activation of microglia mediated by $\mathrm{A} \beta$ binding to APP on microglia. These studies provide compelling support for dysregulated immune activation in the pathophysiology of AD. A more nuanced understanding of the role of neuroinflammation in the pathogenesis of $\mathrm{AD}$ offers the promise of delivering more effective pharmacotherapies in the treatment of debilitating symptoms.

\section{References}

Bolmont T, Haiss F, Eicke D, Radde R, Mathis CA, Klunk WE, Kohsaka S, Jucker M, Calhoun ME (2008) Dynamics of the microglial/amyloid interaction indicate a role in plaque maintenance. J Neurosci 28:4283-4292. CrossRef Medline

Braak H, Braak E (1991) Neuropathological stageing of Alzheimer-related changes. Acta Neuropathol 82:239-259. CrossRef Medline

Chen X, Walker DG, Schmidt AM, Arancio O, Lue LF, Yan SD (2007) RAGE: a potential target for Abeta-mediated cellular perturbation in Alzheimer's disease. Curr Mol Med 7:735-742. CrossRef Medline

DeKosky ST, Scheff SW (1990) Synapse loss in frontal cortex biopsies in Alzheimer's disease: correlation with cognitive severity. Ann Neurol 27:457-464. CrossRef Medline

Edison P, Archer HA, Gerhard A, Hinz R, Pavese N, Turkheimer FE, Hammers A, Tai YF, Fox 
N, Kennedy A, Rossor M, Brooks DJ (2008) Microglia, amyloid, and cognition in Alzheimer's disease: An [11C](R)PK11195-PET and [11C]PIB-PET study. Neurobiol Dis 32:412419. CrossRef Medline

Hardy J, Selkoe DJ (2002) The amyloid hypothesis of Alzheimer's disease: progress and problems on the road to therapeutics. Science 297: 353-356. CrossRef Medline

Heppner FL, Ransohoff RM, Becher B (2015) Immune attack: the role of inflammation in Alzheimer disease. Nat Rev Neurosci 16:358 372. CrossRef Medline

Hong S, Beja-Glasser VF, Nfonoyim BM, Frouin A, Li S, Ramakrishnan S, Merry KM, Shi Q, Rosenthal A, Barres BA, Lemere CA, Selkoe DJ, Stevens B (2016) Complement and microglia mediate early synapse loss in Alzheimer mouse models. Science 352:712-716. CrossRef Medline

Hsia AY, Masliah E, McConlogue L, Yu GQ, Tatsuno G, Hu K, Kholodenko D, Malenka RC, Nicoll RA, Mucke L (1999) Plaque-independent disruption of neural circuits in Alzheimer's disease mouse models. Proc Natl Acad Sci U S A 96:3228-3233. CrossRef Medline

Kettenmann H, Kirchhoff F, Verkhratsky A (2013) Microglia: new roles for the synaptic stripper. Neuron 77:10-18. CrossRef Medline Manocha GD, Floden AM, Rausch K, Kulas JA,
McGregor BA, Rojanathammanee L, Puig KR, Puig KL, Karki S, Nichols MR, Darland DC, Porter JE, Combs CK (2016) APP regulates microglial phenotype in a mouse model of Alzheimer's disease. J Neurosci 36:84718486. CrossRef Medline

McGeer PL, Itagaki S, McGeer EG (1988) Expression of the histocompatibility glycoprotein HLA-DR in neurological disease. Acta Neuropathol 76:550-557. CrossRef Medline

Meyer-Luehmann M, Spires-Jones TL, Prada C, Garcia-Alloza M, de Calignon A, Rozkalne A, Koenigsknecht-Talboo J, Holtzman DM, Bacskai BJ, Hyman BT (2008) Rapid appearance and local toxicity of amyloid-beta plaques in a mouse model of Alzheimer's disease. Nature 451:720-724. CrossRef Medline

Mucke L, Masliah E, Yu GQ, Mallory M, Rockenstein EM, Tatsuno G, Hu K, Kholodenko D, Johnson-Wood K, McConlogue L (2000) Highlevel neuronal expression of abeta 1-42 in wild-type human amyloid protein precursor transgenic mice: synaptotoxicity without plaque formation. J Neurosci 20:4050-4058. Medline

Nimmerjahn A, Kirchhoff F, Helmchen F (2005) Resting microglial cells are highly dynamic surveillants of brain parenchyma in vivo. Science 308:1314-1318. CrossRef Medline

Rezaie P, Male D (2002) Mesoglia and microglia: a historical review of the concept of mononuclear phagocytes within the central nervous system. J Hist Neurosci 11:325-374. CrossRef Medline

Sevigny J, Chiao P, Bussière T, Weinreb PH, Williams L, Maier M, Dunstan R, Salloway S, Chen T, Ling Y, O'Gorman J, Qian F, Arastu M, Li M, Chollate S, Brennan MS, QuinteroMonzon O, Scannevin RH, Arnold HM, Engber T, et al. (2016) The antibody aducanumab reduces Abeta plaques in Alzheimer's disease. Nature 537:50-56. CrossRef Medline

Wake H, Moorhouse AJ, Jinno S, Kohsaka S, Nabekura J (2009) Resting microglia directly monitor the functional state of synapses in vivo and determine the fate of ischemic terminals. J Neurosci 29:3974-3980. CrossRef Medline

Walsh DM, Klyubin I, Fadeeva JV, Cullen WK, Anwyl R, Wolfe MS, Rowan MJ, Selkoe DJ (2002) Naturally secreted oligomers of amyloid beta protein potently inhibit hippocampal long-term potentiation in vivo. Nature 416:535-539. CrossRef Medline

Wyss-Coray T, Rogers J (2012) Inflammation in Alzheimer disease: a brief review of the basic science and clinical literature. Cold Spring Harb Perspect Med 2:a006346. CrossRef Medline 